\title{
Using Risk Characteristics to Classify Funds
}

\author{
Joe Kainja \\ Correspondence: Joe Kainja, Chief Executive and Chief Investment Officer, JoPhi Capital, Johannesburg, South Africa.
}

Received: August 17, 2016

doi:10.11114/afa.v4i2.3461

\author{
Accepted: July 11, 2018 \\ Available online: July 19, 2018 \\ URL: https://doi.org/10.11114/afa.v4i2.3461
}

\begin{abstract}
We analyzed the South African general equity unit trusts for the period 30 June 2002 to 31 December 2014 to assess if we can re-categorize them into risk homogeneity groups. The current ASISA standards do not fully classify the unit trusts into categories that have within-group homogeneity and between-group heterogeneity.

By analyzing the persistence of both systematic and total risk we concluded that we could objectively classify these unit trusts into objective risk homogeneity groups and improve on the current ASISA-mandate-based classification.
\end{abstract}

Keywords: ASISA, unit trusts, mandate, performance, return, risk, persistence, objective classification, contingency tables

\section{Introduction}

We assessed the persistence of risk measures of the general equity unit trusts by analyzing their quartile risk rankings and investigating if the unit trusts that had high risk characteristics in one 12-month period continued to be so in the following 12-month period. We approached this by applying a systematic rule based on quartile rankings of their historic risk measures using contingency tables. Our premise was simple - if the ranking of risk was persistent from period to period then we could use this to classify the unit trusts into risk homogeneous groups.

This technique has been utilized extensively when assessing the persistence of returns. We extended the argument and stated that if the risk across the unit trusts is purely random then one would expect probabilities of $25 \%$ in each quartile from year to year. In other words, there would be an equal probability of a top quartile risk-ranked unit trust in one period to end up in any one of the four quartiles in the following period.

This was a similar approach employed by Dunn and Theisen (1983), Hendricks, Patel and Zeckhauser (1993), Malkiel (1995), Brown and Goetzman (1995), Kahn and Rudd (1995), Brown, Draper and McKenzie (1997), Blake and Timmermann (1998), and Allen and Tan (1999) when testing for persistence of returns. This has become a standard test for persistence of quartile performance rankings. We analysed the persistence of both systematic (beta) and total risk (volatility).

\subsection{Classification of Funds}

With trillions of rands invested in equity unit trusts, it is of major importance for investors to be able to determine which fund, asset manager or investment style is appropriate for their needs. The investor needs to have tools that he can use to make that determination. There are many ways to organize and classify unit trusts. Some investors classify them by their investment styles, some by sectors, some by historic performance and some by the asset management company. Still others will classify funds simply by their defined investment objective and / or description of their investment style classification. Frequently this classification is done without further verification as to whether the categories are correct or if the funds are indeed in their appropriate groups.

The definition of the equity unit trust categories, for example, the Equity-General, is sometimes so broad that it allows for a wide range of different investment policies and philosophies. The definitions have great latitude and the investment objectives are wide, hence there is a need for style classifications that are objectively and empirically determined (Brown and Goetzmann, 1997). These authors further recommended that these classifications should be consistent across managers and should have a correlation with the fund strategy and the investment style. Objectivity is important because there are hazards inherent in allowing managers to self-report their investment management styles without objective verification, they concluded.

Kainja (2016) established that the ASISA classification of the South African equity unit trusts into Equity-General, 
Equity-Value and Equity-Growth was not appropriate, for the period ended 31 December 2011, in that the majority of the funds in those categories did not seem to belong to their allotted group. The results were similar to the findings of Robertson, Firer and Bradfield (2000) - a South African study - as well as a number of global studies, Xue-jun and Xiao-lan (2003) in China, Castellanos and Alonso (2005) in Spain as well as DiBartolomeo and Witkowski (1997) in the US. These results imply that the inferences that are made about the unit trusts relative to their peers may be misleading.

Indeed, Kainja (2016) showed strong evidence of misclassification of the SA equity unit trusts, implying that it might be misleading to an investor wishing to use such a classification as a basis for investment decisions as premised by Najand and Prather (1999). ASISA has since collapsed the three groups into one. We have analysed the combined group to assess if it had actually become one homogenous group or if it required to be reclassified into smaller objective and homogeneous subgroups. Kainja (2016) indicated that these unit trusts were not homogeneous and that it is worthwhile to try and objectively re-classify them. The results further indicated that these funds indeed carry different levels of risk. It is important that the investment objectives convey the risks that the investor is willing to take. Najand and Prather (1999) further demonstrated that if the risks were heterogeneous within an investment group, the practice of comparing performance would not be optimal. Prather (2012) concluded that if the risks of the funds within an investment objective group differ, comparing returns alone is insufficient to make utility maximizing investment decisions. It was from these premises that we were motivated to reclassify these funds into objective groups reflecting their risk-return characteristics.

\subsection{Literature Review}

Historically, investors have used mostly qualitative methods and the natural description of funds (value, growth, index, etc.) as a way to differentiate funds. This judgmental approach, sometimes called static approach, is based on discussions with fund managers (Brown and Goetzmann, 1997) as well as on inspection of the investment philosophy, the historic performance, the fund structure, assets under management and sometimes the brand name. The investors, trustees and the consultants would then hope to differentiate the investment styles of different funds using this data and eventually select suitable funds to meet their requirements. As an example, Integris (www.integrisllc.net) summarized their manager / investment style selection process, which is typical of many pension fund consultants and financial advisors, as follows:

- Define the broad universe of fund managers

- Quantitative screening based on past performance and risk metrics

- Qualitative review based on reputation, assets under management, tenure and references

- Group fund managers with similar characteristics together

- Deep due diligence based on performance attribution, operations and risk factors

- Manager selection and monitoring

The Normal Portfolios technique, also called the Holdings-Based Style Analysis, is another selection and classification process. This methodology was employed by used Brown (2008) to classify funds in South Africa. This consists of analyzing each of the securities that make up the portfolio. The securities are studied and ranked according to the different characteristics that allow their style to be described. The results are then aggregated at the portfolio level to determine the style of the portfolio as a whole. This method therefore requires the present and historical composition of the portfolio, together with the weightings of the different securities that it contains, to be known with precision. The analysis has to be carried out regularly, in order to take into account the evolution of the portfolio composition, as well as the evolution of the characteristics of the securities that make up the portfolio.

The holding-based method requires substantial information on the portfolio, and therefore data availability is a key necessity to applying this methodology. The main weakness of this approach is the frequently subjective character of the classifications. Since the style analyses performed in this approach are specific to each manager, it is usually difficult for them to be reproduced by an external third party. The approach also uses prominent portfolio risk characteristics as a foundation. A manager's normal portfolio represents the universe of securities together with weighting rules that the manager consistently uses to construct portfolios. The normal portfolio is the portfolio the manager would hold in the absence of any investment judgment. Apart from its subjective nature and other weaknesses we have just mentioned, this methodology cannot be applied if the only data that was available was returns as is in the case in our study.

A common quantitative technique that solely uses returns data is Sharpe's (1992) returns-based style analysis discussed in previous chapters. The technique stipulates that a manager's investment style can be determined by comparing the returns of his portfolio with those of a certain number of selected indices or factors. As managers rarely have a pure style, Sharpe (1992) proposed a method whereby one can find the combination of style indices which gives the highest 
R-squared with the returns on the portfolio being studied. R-squared measures the proportion of variance explained by the model, and therefore gives the goodness of fit between the portfolio returns and the returns on the indices.

Recent research findings, including Fama and French (1993), Sharpe (1992), Elton, Gruber and Blake (1996), Carhart (1997), among others, recognized that in performance measurement and asset pricing, the examination of "absolute" return is no longer sufficient and that the investigation of the risks associated in pursuit of the returns are also important. Investment styles and additional factors are being embraced worldwide (Melas and King, 2010). As a result, measurement models of performance need to take into account the existence of these investment styles as risk factors to better measure and explain performance. An example of such models is the Sharpe (1992) 12-factor style-based model for the US mutual funds, which is mathematically expressed as follows:

$$
R_{P j}=\sum F_{i j} \beta_{i j}+\epsilon
$$

where

$R_{P j}$, are returns of Porfolio $\mathrm{j}$

$F_{i j}$ is excess return of a style factor $i$, and

$\beta_{i j}$ is the sentivity of factor $i$ and Portfolio $j$

While Sharpe (1992) recommended 12 factors, the findings of French and Fama (1993) identified that for US equities, there are three consistent and significant drivers (the market, value and size effects) implying that there are at least three distinct groupings. South African studies, including De Villiers, Lowings, Pettit and Affleck-Graves (1986), Page and Palmer (1991), Fraser and Page (2000), Scher and Muller (2005) and more recently Fox and Krige (2013) have also embraced the investment style phenomenon.

It is now accepted that performance studies that omit an adjustment for investment style-risk or even market risk can generate incorrect conclusions. It is hence imperative for an investor to identify the investment styles for the funds of interest. Brown and Goetzmann (1997) recommended the use of returns-based style analysis for monitoring the funds of those managers who perform style rotation, since the changes in their performance patterns can be identified against a set of passive style indices.

Robertson, Firer and Bradfield (2000) used the returns-based style analysis to identify and reclassify the equity unit trusts were that were misclassified by examining if the predominant factor was the correct ASISA PEER average. They reclassified each one of the statistically misclassified unit trusts by identifying a category index that best explained its performance. Since some of the unit trusts were misclassified to start with, the PEER averages were not necessarily genuine representations of the correct PEER average, because they included the misclassified funds in their calculations. They counteracted this problem by recalculating the PEER averages and repeated the process until they obtained convergence. Their results showed that $38 \%$ of the Equity-General unit trusts had to be reclassified into different categories. They concluded that by reclassifying the misclassified funds into their appropriate categories, they created more pure category fund style indices for reporting, benchmarking and analysis purposes.

This returns-based style model has been used extensively across the globe with much success. The success of this technique relies heavily on the correct specification of the style benchmark indices used as regressors. They must correspond to the fund's investment universe and must allow a complete description of the style of the fund. The major advantage of this method is that it does not have a requirement to know the individual securities that make up the portfolio or their proportions. It therefore can be used when there is no data available on the composition of the portfolio. This feature makes this modelling technique extremely attractive.

One of the drawbacks of RBS analysis is that it assumes in advance the number of investment styles that exist, as well as the drivers of those styles. Also, as Trcinka (1995) argued, the returns-based modelling is less useful for diversification and information dissemination purposes. Furthermore, prior studies like Schwert (1989) suggested that style-based models require long-term time series, at least 50 years, to demonstrate reliable relationships. Christopherson (1995) concluded that stock return data can also have very low information content and its use may lead to unreliable estimates. The other weakness of this model is that it does not capture the changes in style by managers. Brown and Goetzmann (1997) found that fund managers intentionally and strategically change investment styles and hence static models may not fully capture their investment styles.

Cluster Analysis is another quantitative methodology that can be employed to classify unit trusts. Following their successful study of clustering common stocks, Bailey and Arnott (1986) concluded that cluster analysis was a simple and yet effective way to categorize funds. Their research findings of fund classification showed that cluster analysis could be used as an effective tool to classify funds into homogeneous groups. Gajendra and Debashis (2007) applied cluster analysis technique to classify mutual funds in India with satisfactory results.

Miceli and Susinno $(2003,2004)$ also effectively used cluster analysis as a methodology to classify various hedge funds 
based on the fund returns. Das (2003) objectively clustered managers based on asset class, style of hedge fund, incentive fee, risk level, and liquidity, using statistical cluster analysis. Gibson and Gyger (2007) concluded that cluster analysis was sufficient to analyze investment styles of mutual funds. Shawky and Marathe (2010) utilized two clustering methodologies to provide an objective method for the satisfactory classification of hedge funds. Lisi and Otranto (2010) also recommended the use of statistical cluster analysis of fund returns as a major tool in classifying mutual funds.

Ferruz and Otriz (2004) analyzed the mutual fund market in India for the period September 2008 to March 2002, comprising a total of 244 mutual funds, using both cluster analysis and factor analysis. Although the aim of their research was to test whether the funds belonged to the correct groups, the analysis involved reclassifying the mutual funds to compare with the original classification. Their results showed that both cluster analysis and factor analysis were useful quantitative tools to create homogeneous groups of unit funds.

Factor analysis is another quantitative technique has been used satisfactorily to group funds, as demonstrated by Ferruz and Otriz (2004). Carhart (1997) identified size and style factors as the major variables in explaining the variation in mutual fund performance and suggested that the related factor loadings would be useful to categorize the mutual funds. Elton and Gruber (1970) applied principal component analysis to classify mutual funds based on latent variable factor loadings. This was the same procedure that Connor and Korajczk (1986), as well as Lehmann and Modest (1987) followed. Brown and Goetzmann (1997) applied a similar methodology to estimate factor loadings when they employed principal component analysis as an alternative classification scheme.

Brown and Goetzmann (1997) used factor analysis to analyse the equity mutual fund data from 1976 to 1994 and found that the funds fell into some familiar and some not-so-familiar patterns of behaviour. The familiar patterns included small-cap, growth, growth and income, income and international. They also identified some unfamiliar categories that are not captured by the traditional objectives that included "trend-chasers" and "glamour" funds. Another interesting finding was that most of the funds classified as growth were actually misclassified. The results also showed that employing factor loadings provided a superior classification technique and improved the results of the original returns-based style analysis.

Fung and Hsieh (2001) used factor axis methodology to classify hedge funds by determining how much variance in the dataset can be explained by common factors (communalities). Shean-Bii and Ching-Pei (1999) had successfully used factor analysis to generate a classification scheme of long-only mutual funds.

The holding-based model requires the analyst to investigate the fund structure, while the returns-based style analysis, the cluster analysis and the factor analysis techniques only require the performance numbers of the funds. If particular funds consistently pursue investment strategies that expose them to similar risks common to particular investment styles and / or represented by specific indices then their returns are expected to be similar and the clustering (cluster and factor analysis) techniques will eventually categorize them accordingly. Both cluster analysis and factor analysis retain the simplicity and ease of application of the qualitative approach, and incorporate quantitative rigour in the evaluation of the past performance patterns of funds. However the both suffer from lack of objectivity when it comes to the number of groups. Either the analyst chooses the number they want in advance or they cut off at some abstract level.

In our research we searched for a technique that would categorize the funds into simple and clear quartiles with an objective discrimination level between the groups. To that end we propose Chi-squared analysis as our objective methodology of classification. This follows from the use of Chi-square test the discriminant level of SA equity unit trusts, Kainja (2016).

\subsection{Chi-Squared Analysis of Contingence Tables}

There is a lot that a contingency table can tell you if you ask the right questions including: what are the odds that a relationship between a row and a column might have occurred just by chance? In the analysis of the persistence of the risk this is the simple question that we were asking. Chi-square is used to calculate the probability that a relationship found in a sample between two variables is due to chance, (Rencher, 2012). In our investigation we found that using chi-square successfully answered our question whether the ranking in the following period was not influenced by the ranking in the previous period - in other words there was no persistence in the rankings of the risk measures.

One of the major advantages of using chi-square test is that it is non-parametric in nature and hence it accepts much weaker and less accurate data and it is hence more forgiving. To that end, we believe that chi-square is a sufficient analytical tool for our investigation into risk persistence using historic rankings of risk measures.

Using 12-month returns we computed both beta and volatility for each of the unit trusts to periods ended 31 December. Once we calculated the risk, we ranked the portfolio returns and assigned each fund a quartile rank. To calculate the beta we used three benchmarks - ALSI, SWIX and PEER as defined below. 
Three separate benchmarks, representing the market, were used for all the categories namely; the FTSE/JSE All Share Index (ALSI), the FTSE/JSE Shareholder-weighted All Share Index (SWIX) and the PEER average (PEER). The ALSI is a free float market capitalization index consisting of about 165 shares. The SWIX has the same constituents but adjusts the weighting of each share to take into account the local availability by removing the proportion of shares held by non-SA residents. The ALSI and the SWIX are published daily and are official JSE indices. The PEER index was calculated using the average performance of the data of all the available equity unit trusts at the time, similar to DiBartolomeo and Witkowski (1997) as well as Robertson, Firer and Bradfield (2000).

\section{Data}

Twelve and a half years of monthly total return data of South African unit trusts was obtained from InetBFA for the period (30 June 2002 to 31 December 2014). Table 1 presents the sample size of the data. Our sample started with the equity unit trusts that were available to investors as at 31 December 2012, the date before ASISA reclassified the unit trusts. The other criterion was that the unit trust had enough historical returns to provide meaningful statistical power for our results. We used 3 calendar years of historical returns as the minimum length of the time series. This followed the works of Carlson (1970), McDonald (1974), Klemkosky (1976), Ippolito (1989), Grinblatt and Titman (1989a,b; 1993), Najand and Prather (1999) and Prather (2012).

Table 1. Number of eligible SA equity unit trusts per category at the end of the year: 2002 to 2014

\begin{tabular}{c|c|c|c|c|c|c|c|c}
\hline Date & General & Value & Growth & Industrials & Resources & Large & Small & Financials \\
\hline 31-Dec-02 & 41 & 7 & 4 & 5 & 7 & 5 & 7 & 5 \\
\hline 31-Dec-03 & 41 & 8 & 4 & 5 & 7 & 5 & 7 & 5 \\
\hline 31-Dec-04 & 42 & 8 & 4 & 5 & 7 & 5 & 7 & 5 \\
\hline 31-Dec-05 & 48 & 8 & 4 & 5 & 7 & 5 & 7 & 6 \\
\hline 31-Dec-06 & 58 & 9 & 4 & 5 & 7 & 5 & 7 & 6 \\
\hline 31-Dec-07 & 66 & 10 & 4 & 5 & 7 & 5 & 7 & 6 \\
\hline 31-Dec-08 & 68 & 10 & 4 & 5 & 7 & 5 & 7 & 6 \\
\hline 31-Dec-09 & 80 & 11 & 6 & 5 & 7 & 5 & 7 & 6 \\
\hline 31-Dec-10 & 83 & 11 & 6 & 5 & 7 & 5 & 7 & 6 \\
\hline 31-Dec-11 & 83 & 11 & 6 & 5 & 7 & 5 & 7 & 6 \\
\hline 31-Dec-12 & 78 & 11 & 6 & 5 & 7 & 5 & 7 & 6 \\
\hline 31-Dec-13 & 89 & & & 5 & 7 & 5 & 7 & 6 \\
\hline 31-Dec-14 & 85 & & & 5 & 7 & 5 & 6 & 6 \\
\hline
\end{tabular}

\section{Methodology}

Our analysis examined the risk persistence of the funds and we tested the following null hypothesis,

$\mathrm{H}_{0}$ : Equity unit trusts do not remain in the same risk - ranked quartile over time

vs

$\mathrm{H}_{1}$ : Equity unit trusts tend to remain in the same risk - ranked quartile over time

We applied the contingence tables of "Quartile Comparison Tables" to conduct the analysis. The Base Period Quartile was developed from the returns achieved by the funds over the initial 12-month period while the Subsequent Period Quartile was the quartile ranking for the following 12 months. If the past performance was a perfect predictor of future performance, we would expect all first quartile funds in the Base Period to be first quartile funds in Subsequent Period same for second, third and fourth quartiles. In other words, we would get a table with $100 \%$ entries in cells on the diagonal from the top left to the bottom right and zeroes everywhere else, as shown in Table 2 below.

Table 2. Quartile comparison table when the past perfectly explains the future

\begin{tabular}{l|c|c|c|c}
\hline & \multicolumn{4}{|c}{ Subsequent Period Quartile } \\
\hline Base Period Quartile & Q1 & Q2 & Q3 & Q4 \\
\hline Q1 & $100 \%$ & $0 \%$ & $0 \%$ & $0 \%$ \\
\hline Q2 & $0 \%$ & $100 \%$ & $0 \%$ & $0 \%$ \\
\hline Q3 & $0 \%$ & $0 \%$ & $100 \%$ & $0 \%$ \\
\hline Q4 & $0 \%$ & $0 \%$ & $0 \%$ & $100 \%$ \\
\hline
\end{tabular}

On the other hand, if there was no predictive power in the past returns, we would see an even distribution of entries throughout as shown in Table 3 below. This table represents our null hypothesis that there was no persistence in the performance rankings of the equity unit trusts. 
Table 3. Quartile comparison table when the past do not explain the future at all

\begin{tabular}{l|c|c|c|c}
\hline & \multicolumn{4}{|c}{ Subsequent Period Quartile } \\
\hline Base Period Quartile & Q1 & Q2 & Q3 & Q4 \\
\hline Q1 & $25 \%$ & $25 \%$ & $25 \%$ & $25 \%$ \\
\hline Q2 & $25 \%$ & $25 \%$ & $25 \%$ & $25 \%$ \\
\hline Q3 & $25 \%$ & $25 \%$ & $25 \%$ & $25 \%$ \\
\hline Q4 & $25 \%$ & $25 \%$ & $25 \%$ & $25 \%$ \\
\hline
\end{tabular}

The more the results deviate from Table 2, the more we should be inclined to believe that there is some explanatory power in the performance rankings. In order to analyze the measure of persistence from one period to the next, we computed the chi-square statistic for each table.

\subsection{Chi-Squared Test}

A chi-squared test, also referred to as chi-square test or $X^{2}$ test, is a statistical hypothesis test in which the sampling distribution of the test statistic is a chi-squared distribution when the null hypothesis is true, or any in which this is asymptotically true, meaning that the sampling distribution (if the null hypothesis is true) - Table 3 - can be made to approximate a chi-squared distribution as closely as desired by making the sample size large enough. The chi-square statistic, $X^{2}$, is computed as follows:

$$
X^{2}=\sum_{i=1}^{r} \sum_{j=1}^{c} \frac{\left(O_{i . j}-E_{i, j}\right)^{2}}{E_{i, j}}
$$

where

$E_{i, j}=\frac{\left(\sum_{n_{c}=1}^{c} O_{i, n_{c}}\right) *\left(\sum_{n_{r}=1}^{r} O_{i, n_{r}, j}\right)}{N}$

$X^{2}=$ Pearson's cumulative test statistic which asymptotically approaches $\chi^{2}$

$O_{i}=$ an observed frequency

$E_{i}=$ an expected (theoretical)frequency, asserted by the null hypothesis, and

$N=$ the number of cells in the table

At $10 \%, 5 \%$ and $1 \%$ significant level, a value of $X^{2}$ greater than $14.7,16.9$ and 19.0, respectively for the overall table or an $X^{2}$ of more than $6.3,7.8$ and 9.3, respectively for a particular row will mean that we will reject the null hypothesis that unit trusts do not remain in the same quartile over time, in other words, the results will suggest that there is some evidence of persistence in the 12-month performance rankings of equity unit trusts. We tested the null hypothesis for each of the 16 periods -8 each for the periods ending on 30 June and 31 December. The investigation tested the persistence of both last year's winners and last year's losers. We completed the analysis by testing for the whole periods.

\section{Results}

The summary results of our analysis are presented below. The detailed results are in the appendix.

Table 4. Summary results of persistence of SA equity unit trust betas relative to SWIX

\begin{tabular}{|l|c|c|c|c|r|c|}
\hline \multicolumn{7}{|c|}{31 December 2002 to 31 December 2014} \\
\hline & Q1 & Q2 & Q3 & Q4 & Chi-square & P-value \\
\hline Q1 & $47 \%$ & $23 \%$ & $18 \%$ & $12 \%$ & 58.86 & $0.00 \%$ \\
\hline Q2 & $29 \%$ & $33 \%$ & $22 \%$ & $16 \%$ & 12.85 & $0.50 \%$ \\
\hline Q3 & $17 \%$ & $24 \%$ & $37 \%$ & $21 \%$ & 18.69 & $0.03 \%$ \\
\hline Q4 & $15 \%$ & $16 \%$ & $23 \%$ & $47 \%$ & 57.82 & $0.00 \%$ \\
\hline & & & & & 148.21 & $0.00 \%$ \\
\hline
\end{tabular}

Table 4 above shows that overall the SA equity unit trusts exhibit persistence of beta relative to SWIX. 
Table 5. Summary results of persistence of SA equity unit trust betas relative to ALSI

\begin{tabular}{|l|r|r|r|r|r|r|}
\hline \multicolumn{7}{|c|}{31 Decenber 2002 to31 Decenber 2014 } \\
\hline & Q1 & Q2 & Q3 & Q4 & Chi-square & P.value \\
\hline Q1 & $51.2 \%$ & $20.7 \%$ & $15.2 \%$ & $12.9 \%$ & 81.97 & $0.00 \%$ \\
\hline Q2 & $27.9 \%$ & $33.2 \%$ & $21.6 \%$ & $17.3 \%$ & 12.12 & $0.70 \%$ \\
\hline Q3 & $13.9 \%$ & $24.9 \%$ & $37.3 \%$ & $23.9 \%$ & 23.13 & $0.00 \%$ \\
\hline Q4 & $11.9 \%$ & $17.6 \%$ & $25.7 \%$ & $44.8 \%$ & 51.83 & $0.00 \%$ \\
\hline & & & & & 169.05 & $0.00 \%$ \\
\hline
\end{tabular}

Similarly, Table 5 above shows that overall the SA equity unit trusts exhibit persistence of beta relative to ALSI.

Table 6. Summary results of persistence of SA equity unit trust betas relative to PEER

\begin{tabular}{|l|c|c|c|c|r|r|}
\hline \multicolumn{7}{|c|}{31 Decenber 2002 to 31 December 2014 } \\
\hline & Q1 & Q2 & Q3 & Q4 & Chisquare & P-value \\
\hline Q1 & $41.0 \%$ & $24.7 \%$ & $18.9 \%$ & $15.4 \%$ & 34.83 & $0.00 \%$ \\
\hline Q2 & $23.9 \%$ & $31.3 \%$ & $25.4 \%$ & $19.4 \%$ & 5.87 & $11.83 \%$ \\
\hline QB & $20.0 \%$ & $26.8 \%$ & $30.2 \%$ & $22.9 \%$ & 4.93 & $17.69 \%$ \\
\hline QA & $17.5 \%$ & $15.2 \%$ & $24.2 \%$ & $43.1 \%$ & 40.66 & $0.00 \%$ \\
\hline & & & & & 86.29 & $0.00 \%$ \\
\hline
\end{tabular}

Table 6 above also shows that overall the SA equity unit trusts exhibit persistence of beta, this time relative to the PEER average.

Table 7. Summary results of volatility persistence of SA equity unit trusts

\begin{tabular}{|l|c|c|c|c|r|r|}
\hline \multicolumn{7}{|c|}{31 Decenber 2002 to 31 December 2014} \\
\hline & Q1 & Q2 & Q3 & Q4 & Chi-square & P-value \\
\hline Q1 & $47.1 \%$ & $22.9 \%$ & $17.1 \%$ & $12.9 \%$ & 59.14 & $0.00 \%$ \\
\hline Q2 & $25.8 \%$ & $28.6 \%$ & $28.6 \%$ & $17.1 \%$ & 7.76 & $5.13 \%$ \\
\hline Q3 & $15.4 \%$ & $29.4 \%$ & $30.8 \%$ & $24.4 \%$ & 12.86 & $0.49 \%$ \\
\hline Q4 & $16.3 \%$ & $17.9 \%$ & $27.6 \%$ & $38.3 \%$ & 24.20 & $0.00 \%$ \\
\hline & & & & & 103.97 & $0.00 \%$ \\
\hline
\end{tabular}

The results illustrated in Tables 4 to 7 show that there is persistence in the risk measures from one year to the next such that by ranking unit trusts according to their risks it is possible to generate objective risk homogeneity groups. Although there were some annual periods that showed lack of persistence the summarized results for the entire period show strong existence of risk homogeneity - be it systematic or total risk. It was also pleasing that results were uniform across the various benchmarks, which we used.

\section{Conclusion}

We found that the risk of South African equity unit trust was persistent form one year to the other to an extent that it would be useful as a classification tool. Contingency table analysis has been extensively used to determine persistence of fund returns. In our research we extended that work to test the persistence of risk characteristics. By analyzing the persistence of both systematic and total risk we concluded that it is possible classify the South African equity unit trusts into objective risk homogeneity groups and improve on the current ASISA-mandate-based classification. We hence propose the use of contingency table quartile analysis as an alternative methodology to objectively classify funds into risk homogeneity groups.

\section{References}

Allen, D. E., \& Tan, M. L. (1999). A Test of the Persistence in the Performance of UK Managed Funds. Journal of Business and Financial Accounting, 26(5-6), 559-593. https://doi.org/10.1111/1468-5957.00267

Arnott, R. D. (1980). Cluster analysis and stock price co-movement. Financial Analysts Journal, 36(6), 56-62. https://doi.org/10.2469/faj.v36.n6.56

Bailey, J, V., \& Arnott, R. D. (1986). Cluster analysis and manager selection. Financial Analysts Journal, 42(6), 20-28. https://doi.org/10.2469/faj.v42.n6.20 
Blake, B., \& Timmerman, A. (1998). Mutual Fund Performance: Evidence from the UK. Review of Finance, 2(1), 5777. https://doi.org/10.1023/A:1009729630606

Bogle, J. C. (1992). Selecting equity mutual funds. The Journal of Portfolio Management, 18(2), 94-100. https://doi.org/10.3905/jpm.1992.409402

Brown, G. P. D., \& McKenzie, E. (1997). Consistency of UK Pension Fund Performance, Journal of Business Finance and Accounting, 24, 155-178. https://doi.org/10.1111/1468-5957.00100

Brown, S. J., \& Goetzmann, W. N. (1995). Performance persistence. The Journal of Finance, 50(2), 697-698. https://doi.org/10.1111/j.1540-6261.1995.tb04800.x

Brown, S. J., \& Goetzmann, W. N. (1997). Mutual fund styles. Journal of Financial Economics, 43, 373-399. https://doi.org/10.1016/S0304-405X(96)00898-7

Brown, W. G. P. (2008). Fund and manager characteristics: determinants of investment performance. PhD Dissertation at the University of Stellenbosch Business School. http://hdl.handle.net/10019.1/1244

Carhart, M. M. (1997). On Persistence in Mutual Fund Performance. The Journal of Finance, 52(1), 57-82. https://doi.org/10.1111/j.1540-6261.1997.tb03808.x

Carlson, R. S. (1970). Aggregate performance of mutual funds, 1948-1967. Journal of Financial and Quantitative Analysis, 5(1), 1-32.

Castellanos, A. R., \& Alonso, B. V. (2005). Spanish mutual fund misclassification; empirical evidence. Journal of Investing, 14(1), 41-51. https://doi.org/10.3905/joi.2005.479388

Connor, G., \& Korajczk, R. A. (1991). The attributes, behaviour and performance of US mutual funds. Review of Quantitative Finance and Accounting, 1, 5-26. https://doi.org/10.1007/BF02408404

Das, N. (2003). Hedge fund classification using K-means clustering method. 9th International Conference on Computing in Economics and Finance, University of Washington, Seattle. https://pdfs.semanticscholar.org/a62e/f9f969bb4142599edf2e6b64fc041113873c.pdf

De Villiers, P., Lowings, A. J., Pettit, T., \& Aflleck, G. J. (1986). An investigation into the small firm effect on the Johannesburg Stock Exchange. South African Journal of Business Management, 17(4), 191 - 195. http:/hdl.handle.net/10520/EJC-64d574454

Detzel, F. L. (2006). Determining a mutual fund's equity class. Financial Services Review, 15(3), 199-212. https://search.proquest.com/openview/8951ff45787628be5ae2ddf590866048/1?pq-origsite $=$ gscholar\&cbl=31458

DiBartolomeo, D., \& Witkowski, E. (1997). Mutual fund misclassification: evidence based on style analysis. Financial Analysts Journal, 32-43. https://doi.org/10.2469/faj.v53.n5.2115

Dunn, P. C., \& Theisen, R. D. (1983). How consistently do active managers win? The Journal of Portfolio Management. 9(4), 47-50. https://doi.org/10.3905/jpm.1983.47

Elton, E. J., \& Gruber, M. J. (1970). Homogeneous Groups and the Testing of Economic Hypotheses. Journal of Quantitative and Financial Analysis, 4(5), 581-602. https://doi.org/10.2307/2330115

Elton, E. J., Gruber, M. J., \& Blake, C. R. (1996). The Persistence of Risk-Adjusted Mutual Fund Performance. The Journal of Business, 69(2), 133-157. https://doi.org/10.1086/209685

Fama, E. F., \& French, K. R. (1993). Common risk factors in the returns on stocks and bonds. Journal of Financial Economics, 33(1), 3-56. https://doi.org/10.1016/0304-405X(93)90023-5

Farrel, J. (1975). Homogeneous stock groupings: implications for portfolio management. Financial Analysts Journal, 31(3), 50. https://doi.org/10.2469/faj.v31.n3.50

Filip, D. (2011). Performance persistence of equity funds in Hungry. Contemporary Economics, 5(1), 18-34. https://doi.org/10.5709/ce.1897-9254.2

Fox, M. A., \& Krige, J. D. (2013). Investigating the sources of performance in South African general equity unit trusts. $\begin{array}{llll}\text { Investment Analysts } & \text { Journal, }\end{array}$ http://www.tandfonline.com/doi/abs/10.1080/10293523.2013.11082555

Fraser, E., \& Page, M. (2000). Value and momentum strategies: Evidence from the Johannesburg Stock Exchange. $\begin{array}{llll}\text { Investment Analysts } & \text { Journal, } & \text { 29(51), }\end{array}$ http://www.tandfonline.com/doi/abs/10.1080/10293523.2000.11082404?journalCode=riaj20

Fung, W., \& Hsieh, D. A. (2001). The risk in hedge fund strategies: Theory and evidence from trend followers. The Review of Financial Studies, 14(2), 313-341. 
Gajendra, S., \& Debashis, A. (2007). Classifying mutual funds in India: some results from clustering. Indian Journal of Economics and Business, 6(1), 71-79. https://ssrn.com/abstract=999856

Gibson, R., \& Gyger, S. (2007). The Style Consistency of Hedge Funds. European Financial Management, 13(2), 287308. https://doi.org/10.1111/j.1468-036X.2006.00355.x

Grinblatt, M., \& Titman, S. (1989). Portfolio Performance Evaluation: Old Issues and New Insights. The Review of Financial Studies, 2(3), 393-421. https://doi.org/10.1093/rfs/2.3.393

Grinblatt, M., \& Titman, S. (1992). Persistence in mutual fund performance. Journal of Finance, 47, 1977-1984. https://doi.org/10.1111/j.1540-6261.1992.tb04692.x

Hendricks, D., Patel, J., \& Zeckhauser, R. (1993). Hot Hands in Mutual Funds: Short Run Persistence of Relative Performance. Journal of Finance, 48, 93-130. https://doi.org/10.1111/j.1540-6261.1993.tb04703.x

Ippolito, R. A. (1989). Efficiency with costly information: A study of mutual fund performance, 1965-1984. The Quarterly Journal of Economics, 104(1), 1-23.

Kainja, J. (2016). Are the ASISA Standards with Respect to Unit Trust Classification Representative of Homogeneous Risk Classes? Journal of Financial Risk Management, 05, 63-80. https://doi.org/10.4236/jfrm.2016.52008

Kim, M., Shukla, R., \& Tomas, M. (2000). Mutual fund objective misclassification. Journal of Economics and Business, 52(4), 309-323. https://doi.org/10.1016/S0148-6195(00)00022-9

Klemkosky, R. C. (1976). Additional evidence on the risk level discrimination powers of the Wiesenberger classifications. The Journal of Business, 49(1), 48.50. https://doi.org/10.1086/295804

Lehmann, B. N., \& Modest, D. M. (1987). Mutual Fund Performance Evaluation: A Comparison of Benchmarks and Benchmark Comparisons. The Journal of Finance. 42(2), 233-265. https://doi.org/10.1111/j.1540-6261.1987.tb02566.x

Lisi, F., \& Otranto, E. (2010). Clustering mutual funds by return and risk. Mathematical and Statistical Methods for Actuarial Sciences and Finance, Springer. https://doi.org/10.1007/978-88-470-1481-7_19

McDonald, J. G. (1974). Objectives and Performance of Mutual Funds, 1960-1969. Journal of Financial and Quantitative Analysis, 9(3), 311-333. DOI: https://doi.org/10.2307/2329866.

Melas, D., \& Kang, X. (2010). Applications of systematic indices in the investment process. MSCI Research.

Meyer, M. C. (1998). The persistence of unit trusts performance for the period July 1985-June 1995. South African Journal of Business Management, 29(3), 100-108. http://hdl.handle.net/10520/EJC-6821510de

Miceli, M. A., \& Susinno, G. (2003). Using trees to grow money. Risk, 16(11), 11-12. https://ssrn.com/abstract=478441

Miceli, M. A., \& Susinno, G. (2004). Ultrametricity in fund of fund diversification. Physica A. 344(1-2), 95-99. https://doi.org/10.1016/j.physa.2004.06.094

Najand, M., \& Prather, L. J. (1999). The risk level discriminatory power of mutual fund objectives: additional evidence. Journal of Financial Markets, 2, 307-328. https://doi.org/10.1016/S1386-4181(99)00002-6

Page, M. J., \& Palmer, F. (1991). The relationship between excess returns, firm size and earnings on the Johannesburg Stock Exchange: an empirical analysis. South African Journal of Business Management. 22(3). http://hdl.handle.net/10520/EJC-6751b340d

Prather, L. J. (2012). Portfolio risk management implications of mutual fund investment objective classifications. Journal of Financial Risk Management, 1(3), 33-37. https://doi.org/10.4236/jfrm.2012.13006

Rencher, A. C. (2002). Methods of multivariate analysis. Wiley Series in Probability and Statistics. John Wiley \& Sons, Inc. (2002). Second Edition. https://doi.org/10.1002/0471271357

Robertson, M., Firer, C., \& Bradfield, D. (2000). Identifying and correcting misclassified South African equity trusts using style analysis. Investments Analyst Journal, 52, 11-24. http://www.tandfonline.com/doi/abs/10.1080/10293523.2000.11082409?journalCode=riaj20

Scher, N., \& Muller, C. (2005). Equity style and performance persistence in South African unit trusts. Investment Analysts Journal, $\quad 61, \quad 5-16$. http://www.tandfonline.com/doi/abs/10.1080/10293523.2005.11082464?journalCode=riaj20

Sharpe, W. F. (1992). Asset allocation: management style and performance measurement. Journal of Portfolio Management, 18(2), 7-19. https://doi.org/10.3905/jpm.1992.409394

Shawky, H. A., \& Marathe, A. (2010). Stylistics differences across hedge funds as revealed by historic monthly returns. 
Technology and Investments, 2, 26-34. https://doi.org/10.4236/ti.2010.11004

Windham, M. P. (2002). Robust objective function cluster analysis. Journal of Classification. http://www.michaelpwindham.com/clustering/robustcluster.pdf

Windmeier, F. A., G. (1995). Goodness of fit measures in binary response models. Econometric Review, 14(1), 101-116. https://doi.org/10.1080/07474939508800306

Xue, J. J., \& Xiao, L. Y. (2003). Empirical study on mutual fund objective classification. Journal of Zhejiang University Science, 5(5), 533-538. https://doi.org/10.1631/jzus.2004.0533

\section{Appendix}

Below we present detailed results of the analysis.

Table 8. Persistence of SA equity unit trust betas relative to SWIX - annual results

\begin{tabular}{|l|r|r|r|r|r|r|r|r|r|r|r|r|r|}
\hline \multicolumn{7}{|c|}{ 12 Months Ended 31 Dec 2004 } & \multicolumn{6}{|c|}{ 12 Months Ended 31 Dec 2005 } \\
\hline & Q1 & Q2 & Q3 & Q4 & Chi-square & P-value & & Q1 & Q2 & Q3 & Q4 & Chi-square & P-value \\
\hline Q1 & $53.8 \%$ & $30.8 \%$ & $7.7 \%$ & $7.7 \%$ & 7.6 & $5 \%$ & Q1 & $69.2 \%$ & $7.7 \%$ & $15.4 \%$ & $7.7 \%$ & 13.8 & $0 \%$ \\
\hline Q2 & $23.1 \%$ & $46.2 \%$ & $15.4 \%$ & $15.4 \%$ & 3.3 & $35 \%$ & Q2 & $21.4 \%$ & $50.0 \%$ & $21.4 \%$ & $7.1 \%$ & 5.4 & $14 \%$ \\
\hline Q3 & $21.4 \%$ & $7.1 \%$ & $50.0 \%$ & $21.4 \%$ & 5.4 & $14 \%$ & Q3 & $0.0 \%$ & $35.7 \%$ & $35.7 \%$ & $28.6 \%$ & 4.9 & $18 \%$ \\
\hline Q4 & $0.0 \%$ & $21.4 \%$ & $28.6 \%$ & $50.0 \%$ & 7.1 & $7 \%$ & Q4 & $0.0 \%$ & $0.0 \%$ & $30.8 \%$ & $69.2 \%$ & 16.8 & $0 \%$ \\
\hline & & & & & 23.5 & $1 \%$ & & & & & & 40.9 & $0 \%$ \\
\hline
\end{tabular}

\begin{tabular}{|l|r|r|r|r|r|r|r|r|r|r|r|r|r|}
\hline \multicolumn{7}{|c|}{12 Months Ended 31 Dec 2006 } & \multicolumn{6}{|c|}{12 Months Ended 31 Dec 2007 } \\
\hline & Q1 & Q2 & Q3 & Q4 & Chi-square & P-value & Q1 & Q2 & Q3 & Q4 & Chi-squar P-value \\
\hline Q1 & $46.2 \%$ & $23.1 \%$ & $23.1 \%$ & $7.7 \%$ & 3.9 & $27 \%$ & Q1 & $46.7 \%$ & $26.7 \%$ & $20.0 \%$ & $6.7 \%$ & 5.0 & $17 \%$ \\
\hline Q2 & $21.4 \%$ & $35.7 \%$ & $42.9 \%$ & $0.0 \%$ & 6.0 & $11 \%$ & Q2 & $40.0 \%$ & $33.3 \%$ & $20.0 \%$ & $6.7 \%$ & 3.9 & $27 \%$ \\
\hline Q3 & $0.0 \%$ & $28.6 \%$ & $28.6 \%$ & $42.9 \%$ & 5.4 & $14 \%$ & Q3 & $20.0 \%$ & $26.7 \%$ & $33.3 \%$ & $20.0 \%$ & 0.7 & $87 \%$ \\
\hline Q4 & $31.3 \%$ & $18.8 \%$ & $6.3 \%$ & $43.8 \%$ & 5.0 & $17 \%$ & Q4 & $0.0 \%$ & $0.0 \%$ & $26.7 \%$ & $73.3 \%$ & 21.5 & $0 \%$ \\
\hline & & & & & 20.4 & $2 \%$ & & & & & & 31.2 & $0 \%$ \\
\hline
\end{tabular}

\begin{tabular}{|l|r|r|r|r|r|r|r|r|r|r|r|r|r|}
\hline \multicolumn{7}{|c|}{ 12 Months Ended 31 Dec 2008 } & \multicolumn{1}{|c|}{ 12 Months Ended 31 Dec 2009 } \\
\hline & Q1 & Q2 & Q3 & Q4 & Chi-square & P-value & & Q1 & Q2 & Q3 & Q4 & Chi-square & P-value \\
\hline Q1 & $22.2 \%$ & $27.8 \%$ & $22.2 \%$ & $27.8 \%$ & 0.2 & $97 \%$ & Q1 & $26.3 \%$ & $42.1 \%$ & $15.8 \%$ & $15.8 \%$ & 3.5 & $32 \%$ \\
\hline Q2 & $27.8 \%$ & $33.3 \%$ & $22.2 \%$ & $16.7 \%$ & 1.1 & $77 \%$ & Q2 & $25.0 \%$ & $25.0 \%$ & $35.0 \%$ & $15.0 \%$ & 1.6 & $66 \%$ \\
\hline Q3 & $18.8 \%$ & $18.8 \%$ & $43.8 \%$ & $18.8 \%$ & 3.0 & $39 \%$ & Q3 & $25.0 \%$ & $5.0 \%$ & $50.0 \%$ & $20.0 \%$ & 8.4 & $4 \%$ \\
\hline Q4 & $22.2 \%$ & $27.8 \%$ & $11.1 \%$ & $38.9 \%$ & 2.9 & $41 \%$ & Q4 & $20.0 \%$ & $20.0 \%$ & $10.0 \%$ & $50.0 \%$ & 7.2 & $7 \%$ \\
\hline & & & & & 7.2 & $61 \%$ & & & & & & 20.7 & $1 \%$ \\
\hline
\end{tabular}

\begin{tabular}{|l|r|r|r|r|r|r|r|r|r|r|r|r|r|}
\hline \multicolumn{10}{|c|}{12 Months Ended 31 Dec 2010 } & \multicolumn{7}{|c|}{ 12 Months Ended 31 Dec 2011 } \\
\hline & Q1 & Q2 & Q3 & Q4 & Chi-square & P-value & & Q1 & Q2 & Q3 & Q4 & Chi-squar & P-value \\
\hline Q1 & $38.1 \%$ & $28.6 \%$ & $19.0 \%$ & $14.3 \%$ & 2.8 & $42 \%$ & Q1 & $66.7 \%$ & $12.5 \%$ & $20.8 \%$ & $0.0 \%$ & 24.3 & $0 \%$ \\
\hline Q2 & $52.4 \%$ & $33.3 \%$ & $4.8 \%$ & $9.5 \%$ & 12.3 & $1 \%$ & Q2 & $20.8 \%$ & $45.8 \%$ & $20.8 \%$ & $12.5 \%$ & 6.0 & $11 \%$ \\
\hline Q3 & $17.4 \%$ & $21.7 \%$ & $47.8 \%$ & $13.0 \%$ & 6.7 & $8 \%$ & Q3 & $8.0 \%$ & $36.0 \%$ & $36.0 \%$ & $20.0 \%$ & 5.6 & $14 \%$ \\
\hline Q4 & $0.0 \%$ & $13.6 \%$ & $31.8 \%$ & $54.5 \%$ & 14.7 & $0 \%$ & Q4 & $4.0 \%$ & $4.0 \%$ & $24.0 \%$ & $68.0 \%$ & 27.3 & $0 \%$ \\
\hline & & & & & 36.6 & $0 \%$ & & & & & & 63.2 & $0 \%$ \\
\hline
\end{tabular}

\begin{tabular}{|l|r|r|r|r|r|r|r|r|r|r|r|r|r|}
\hline \multicolumn{10}{|c|}{12 Months Ended 31 Dec 2012 } & \multicolumn{1}{|c|}{ 12 Months Ended 31 Dec 2013 } \\
\hline & Q1 & Q2 & Q3 & Q4 & Chi-square & P-value & Q1 & Q2 & Q3 & Q4 & Chi-square & P-value \\
\hline Q1 & $50.0 \%$ & $37.5 \%$ & $8.3 \%$ & $4.2 \%$ & 14.3 & $0 \%$ Q1 & $54.2 \%$ & $4.2 \%$ & $20.8 \%$ & $25.0 \%$ & 12.5 & $1 \%$ \\
\hline Q2 & $37.5 \%$ & $29.2 \%$ & $12.5 \%$ & $25.0 \%$ & 3.2 & $37 \%$ Q2 & $16.7 \%$ & $25.0 \%$ & $33.3 \%$ & $20.8 \%$ & 1.5 & $68 \%$ \\
\hline Q3 & $20.0 \%$ & $16.0 \%$ & $32.0 \%$ & $32.0 \%$ & 2.0 & $56 \%$ Q3 & $20.0 \%$ & $40.0 \%$ & $28.0 \%$ & $8.0 \%$ & 5.5 & $14 \%$ \\
\hline Q4 & $8.0 \%$ & $16.0 \%$ & $44.0 \%$ & $36.0 \%$ & 8.5 & $4 \%$ & Q4 & $28.0 \%$ & $24.0 \%$ & $8.0 \%$ & $32.0 \%$ & 3.5 & $32 \%$ \\
\hline & & & & & 28.1 & $0 \%$ & & & & & 23.0 & $1 \%$ \\
\hline
\end{tabular}




\begin{tabular}{|l|r|r|r|r|r|r|}
\hline \multicolumn{7}{|c|}{ 12 Months Ended 31 Dec 2014 } \\
\hline & \multicolumn{1}{|c|}{ Q2 } & Q3 & Q4 & Chi-square & P-value \\
\hline Q1 & $54.2 \%$ & $20.8 \%$ & $29.2 \%$ & $16.7 \%$ & 9.2 & $3 \%$ \\
\hline Q2 & $20.8 \%$ & $12.5 \%$ & $16.7 \%$ & $33.3 \%$ & 3.0 & $39 \%$ \\
\hline Q3 & $24.0 \%$ & $20.0 \%$ & $20.0 \%$ & $16.0 \%$ & 1.3 & $72 \%$ \\
\hline Q4 & $32.0 \%$ & $20.0 \%$ & $20.0 \%$ & $12.0 \%$ & 2.7 & $44 \%$ \\
\hline & & & & & 16.2 & $6 \%$ \\
\hline
\end{tabular}

Table 9. Persistence of SA equity unit trust betas relative to ALSI - annual results

\begin{tabular}{|c|c|c|c|c|c|c|c|c|c|c|c|c|}
\hline \multicolumn{7}{|c|}{12 Months Ended 31 Dec 2004} & \multicolumn{6}{|c|}{12 Months Ended 31 Dec 2005} \\
\hline & Q1 & Q2 & & Q4 & Chisquare & P.value & Q1 & Q2 & Q3 & Q4 & Chi-square & P.value \\
\hline Q1 & $60.0 \%$ & $26.7 \%$ & $0.0 \%$ & $13.3 \%$ & 11.9 & $1 \%[01$ & $76.9 \%$ & $15.4 \%$ & $0.0 \%$ & $7.7 \%$ & 19.3 & $0 \%$ \\
\hline Q2 & $13.3 \%$ & $40.0 \%$ & $40.0 \%$ & $6.7 \%$ & 5.5 & $14 \%[Q 2$ & $21.4 \%$ & $57.1 \%$ & $14.3 \%$ & $7.1 \%$ & 8.3 & $4 \%$ \\
\hline Q3 & $13.3 \%$ & $20.0 \%$ & $20.0 \%$ & $46.7 \%$ & 3.9 & $27 \%$ Q3 & $0.0 \%$ & $16.7 \%$ & $58.3 \%$ & $25.0 \%$ & 8.7 & $3 \%$ \\
\hline Q4 & $0.0 \%$ & $11.1 \%$ & $33.3 \%$ & $55.6 \%$ & 6.6 & $9 \%[04$ & $0.0 \%$ & $6.7 \%$ & $33.3 \%$ & $60.0 \%$ & 13.5 & $0 \%$ \\
\hline & & & & & 28.0 & $0 \%$ & & & & & 49.8 & $0 \%$ \\
\hline
\end{tabular}

\begin{tabular}{|c|c|c|c|c|c|c|c|c|c|c|c|c|}
\hline \multicolumn{7}{|c|}{12 Nonths Ended 31 Dec 2006} & \multicolumn{6}{|c|}{12 Months Ended 31 Dec 2007} \\
\hline & Q1 & Q2 & QB & Q4 & Chi-square & P.value & Q1 & Q2 & $Q B$ & Q4 & Chisquare & P.value \\
\hline Q1 & $64.3 \%$ & $14.3 \%$ & $14.3 \%$ & $7.1 \%$ & 11.7 & $1 \%[Q 1$ & $53.3 \%$ & $33.3 \%$ & $6.7 \%$ & $6.7 \%$ & 9.3 & $3 \%$ \\
\hline Q2 & $14.3 \%$ & $35.7 \%$ & $42.9 \%$ & $7.1 \%$ & 4.9 & $18 \%$ Q2 & $25.0 \%$ & $33.3 \%$ & $25.0 \%$ & $16.7 \%$ & 0.7 & $88 \%$ \\
\hline QB & $7.1 \%$ & $14.3 \%$ & $42.9 \%$ & $35.7 \%$ & 4.9 & $18 \%$ Q3 & $12.5 \%$ & $31.3 \%$ & $50.0 \%$ & $6.3 \%$ & 7.5 & $6 \%$ \\
\hline Q4 & $13.3 \%$ & $20.0 \%$ & $13.3 \%$ & $53.3 \%$ & 6.6 & $9 \% / 04$ & $5.9 \%$ & $11.8 \%$ & $17.6 \%$ & $64.7 \%$ & 14.8 & $0 \%$ \\
\hline & & & & & 28.0 & $0 \%$ & & & & & 32.2 & $0 \%$ \\
\hline
\end{tabular}

\begin{tabular}{|c|c|c|c|c|c|c|c|c|c|c|c|c|}
\hline \multicolumn{7}{|c|}{12 Nonths Ended 31 Dec 2008} & \multicolumn{6}{|c|}{12 Months Erded 31 Dec 2009} \\
\hline & Q1 & Q2 & Q3 & QA & Chisquare & P.value & Q1 & Q2 & $Q 3$ & QA & Chisquare & P.value \\
\hline Q1 & $36.8 \%$ & $31.6 \%$ & $15.8 \%$ & $15.8 \%$ & 2.7 & $44 \%$ Q1 & $27.8 \%$ & $38.9 \%$ & $11.1 \%$ & $22.2 \%$ & 2.9 & $41 \%$ \\
\hline Q2 & $38.9 \%$ & $27.8 \%$ & $11.1 \%$ & $22.2 \%$ & 2.9 & $41 \%$ Q2 & $45.0 \%$ & $10.0 \%$ & $30.0 \%$ & $15 . \%$ & 6.0 & $11 \%$ \\
\hline Q3 & $5.9 \%$ & $17.6 \%$ & $41.2 \%$ & $35.3 \%$ & 5.4 & $15 \% Q_{Q 3}$ & $10.0 \%$ & $25.0 \%$ & $45.0 \%$ & $20.0 \%$ & 5.2 & $16 \%$ \\
\hline Q4 & $0.0 \%$ & $31.3 \%$ & $31.3 \%$ & $37.5 \%$ & 5.5 & $14 \%(04$ & $14.3 \%$ & $23.8 \%$ & $19.0 \%$ & $42.9 \%$ & 4.0 & $27 \%$ \\
\hline & & & & & 16.4 & $6 \%$ & & & & & 18.0 & $3 \%$ \\
\hline
\end{tabular}

\begin{tabular}{|c|c|c|c|c|c|c|c|c|c|c|c|c|}
\hline \multicolumn{7}{|c|}{12 Months Ended 31 Dec 2010} & \multicolumn{6}{|c|}{12 Months Ended 31 Dec 2011} \\
\hline & Q1 & Q2 & Q3.3 & QA & Chisquare & P.value & Q1 & Q2 & Q3 & Q4 & Chissouare & P.value \\
\hline Q1 & $52.4 \%$ & $19.0 \%$ & $14.3 \%$ & $14.3 \%$ & 8.5 & $4 \%$ Q1 & $62.5 \%$ & $16.7 \%$ & $20.8 \%$ & $0.0 \%$ & 20.3 & $0 \%$ \\
\hline Q & $31.8 \%$ & $45.5 \%$ & $4.5 \%$ & $18.2 \%$ & 8.2 & $4 \%[02$ & $20.8 \%$ & $45.8 \%$ & $20.8 \%$ & $12.5 \%$ & 6.0 & $11 \%$ \\
\hline QB & $18.2 \%$ & $13.6 \%$ & $54.5 \%$ & $13.6 \%$ & 10.4 & $2 \%$ QB & $12.0 \%$ & $32.0 \%$ & $32.0 \%$ & $24.0 \%$ & 2.7 & $44 \%$ \\
\hline QA & $4.5 \%$ & $18.2 \%$ & $31.8 \%$ & $45.5 \%$ & 8.2 & $4 \%$ QA & $4.0 \%$ & $4.0 \%$ & $28.0 \%$ & $64.0 \%$ & 24.1 & $0 \%$ \\
\hline & & & & & 35.3 & $0 \%$ & & & & & 53.1 & $0 \%$ \\
\hline
\end{tabular}




\begin{tabular}{|c|c|c|c|c|c|c|c|c|c|c|c|c|}
\hline \multicolumn{7}{|c|}{12 Moniths Ended 31 Dec 2012} & \multicolumn{6}{|c|}{12 Morths Ended 31 Dec 2013} \\
\hline & Q1 & Q2 & 13 & Q4 & Chissolare & P.value & at & 12 & QB & $\mathrm{OA}_{4}$ & Chissuare & P.value \\
\hline al & $58.3 \%$ & $20.8 \%$ & $20.8 \%$ a & $0.0 \%$ & 17.0 & $0 \% Q$ & $45.8 \%$ & $12.5 \%$ & 25.09 & $\begin{array}{l}\% \quad 20.8 \% \\
\end{array}$ & 5.8 & $12 \%$ \\
\hline Q & $37.5 \%$ & $37.5 \%$ & $8.3 \%$ & $20.8 \%$ & 5.8 & $12 \% \% \frac{Q 2}{2}-2-2$ & $25.0 \%$ & $25.0 \%$ & 33.39 & $\%$ & 1.3 & $72 \%$ \\
\hline QB & $16.0 \%$ & $20.0 \%$ & $28.0 \%$ & $36.0 \%$ & 2.4 & $50 \% Q_{2}^{2}-2-3$ & $16.0 \%$ & $36.0 \%$ & 20.09 & $\% \quad 20 . \% \%$ & 2.5 & $47 \%$ \\
\hline QA & 4.0\% & $20.0 \%$ & $40.0 \%$ & 40.0\% & 9.2 & $3 \% Q$ & $32.0 \%$ & $20.0 \%$ & 12.09 & $\begin{array}{l}\% \quad 28.0 \% \\
\end{array}$ & 2.5 & $47 \%$ \\
\hline & & & & & 34.4 & $0 \%$ & & & & & 122. & $20 \%$ \\
\hline
\end{tabular}

\begin{tabular}{|l|r|r|r|r|r|r|}
\hline \multicolumn{7}{|c|}{12 Months Ended 31 Dec 2014 } \\
\hline & Q1 & Q2 & Q3 & Q4 & Chi-square & P.value \\
\hline Q1 & $50.0 \%$ & $12.5 \%$ & $25.0 \%$ & $33.3 \%$ & 8.2 & $4 \%$ \\
\hline Q2 & $20.8 \%$ & $12.5 \%$ & $16.7 \%$ & $33.3 \%$ & 3.0 & $39 \%$ \\
\hline Q3 & $24.0 \%$ & $28.0 \%$ & $24.0 \%$ & $4.0 \%$ & 4.5 & $21 \%$ \\
\hline Q4 & $32.0 \%$ & $20.0 \%$ & $20.0 \%$ & $12.0 \%$ & 2.7 & $44 \%$ \\
\hline & & & & & 18.4 & $3 \%$ \\
\hline
\end{tabular}

Table 10. Persistence of SA equity unit trust betas relative to PEER - annual results

\begin{tabular}{|c|c|c|c|c|c|c|c|c|c|c|c|c|}
\hline \multicolumn{7}{|c|}{12 Moniths Ended 31 Dec 2004} & \multicolumn{6}{|c|}{12 Moniths Ended 31 Dec 2005} \\
\hline & Q1 & Q2 & Q3 & Q4 & Chi-square & & Q1 & Q2 & Q3 & Q4 & Chi-square & P-value \\
\hline$Q 1$ & $0.0 \%$ & $7.7 \%$ & $30.8 \%$ & $61.5 \%$ & 11.9 & $1 \% 01$ & $23.1 \%$ & $38.5 \%$ & $30.8 \%$ & $7.7 \%$ & 2.7 & $44 \%$ \\
\hline Q2 & $30.8 \%$ & $15.4 \%$ & $23.1 \%$ & $30.8 \%$ & 0.8 & $84 \% Q_{2}$ & $30.8 \%$ & $15.4 \%$ & $30.8 \%$ & $23.1 \%$ & 0.8 & $84 \%$ \\
\hline$Q 3$ & $0.0 \%$ & $42.9 \%$ & $42.9 \%$ & $14.3 \%$ & 7.7 & $5 \% \mid Q_{2}^{2}$ & $21.4 \%$ & $35.7 \%$ & $14.3 \%$ & $28.6 \%$ & 1.4 & $70 \%$ \\
\hline Q4 & $64.3 \%$ & $28.6 \%$ & $7.1 \%$ & $0.0 \%$ & 14.0 & $0 \% 104$ & $21.4 \%$ & $7.1 \%$ & $28.6 \%$ & $42.9 \%$ & 3.7 & $29 \%$ \\
\hline & & & & & 34.5 & $0 \%$ & & & & & 8.7 & $47 \%$ \\
\hline
\end{tabular}

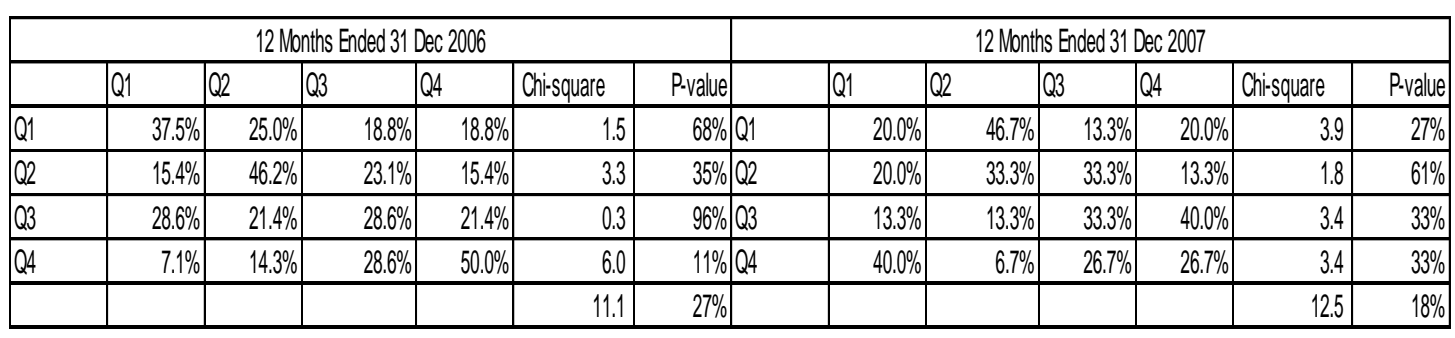

\begin{tabular}{|c|c|c|c|c|c|c|c|c|c|c|c|c|}
\hline \multicolumn{7}{|c|}{12 Months Ended 31 Dec 2008} & \multicolumn{6}{|c|}{12 Moniths Ended 31 Dec 2009} \\
\hline & Q1 & Q2 & Q3 & Q4 & Chi-square & P-value & Q1 & Q2 & Q3 & Q4 & Chi-square & $\begin{array}{l}\text { Pvalue } \\
\end{array}$ \\
\hline$\overline{Q 1}$ & $45.0 \%$ & $30.0 \%$ & $20.0 \%$ & $5.0 \%$ & 6.8 & $8 \%$ Q1 & $45.5 \%$ & $13.6 \%$ & $27.3 \%$ & $13.6 \%$ & 6.0 & $11 \%$ \\
\hline Q2 & $25.0 \%$ & $37.5 \%$ & $25.0 \%$ & $12.5 \%$ & 2.0 & $57 \%$ Q2 & $15.8 \%$ & $31.6 \%$ & $26.3 \%$ & $26.3 \%$ & 1.0 & $80 \%$ \\
\hline$\overline{Q 3}$ & $23.5 \%$ & $29.4 \%$ & $23.5 \%$ & $23.5 \%$ & 0.2 & $98 \%$ Q3 & $10.5 \%$ & $31.6 \%$ & $42.1 \%$ & $15.8 \%$ & 4.8 & $19 \%$ \\
\hline Q4 & $5.9 \%$ & $5.9 \%$ & $29.4 \%$ & $58.8 \%$ & 12.9 & $0 \%[04$ & $21.1 \%$ & $21.1 \%$ & $5.3 \%$ & $52.6 \%$ & 9.0 & $3 \%$ \\
\hline & & & & & 21.9 & $1 \%$ & & & & & 20.8 & $1 \%$ \\
\hline
\end{tabular}




\begin{tabular}{|c|c|c|c|c|c|c|c|c|c|c|c|c|}
\hline \multicolumn{7}{|c|}{12 Nonths Ended 31 Dec 2010} & \multicolumn{6}{|c|}{12 Nonths Ended 31 Dec 2011} \\
\hline & $Q 1$ & Q2 & Q3 & AA & Chi-square & P.value & 01 & Q2 & QB & Q4 & Chis-square & P.value \\
\hline Q1 & $34.6 \%$ & $38.5 \%$ & $11.5 \%$ & $15.4 \%$ & 5.7 & $13 \% \mid Q 1$ & $41.4 \%$ & $20.7 \%$ & $20.7 \%$ & $17.2 \%$ & 4.2 & $24 \%$ \\
\hline Q2 & $20.0 \%$ & $25.0 \%$ & $30.0 \%$ & $25.0 \%$ & 0.4 & $94 \%$ Q2 & $39.1 \%$ & $47.8 \%$ & $0.0 \%$ & $13.0 \%$ & 13.7 & $0 \%$ \\
\hline$Q B$ & $25.0 \%$ & $15.0 \%$ & $45.0 \%$ & $15.0 \%$ & 4.8 & $19 \% / 03$ & $13.0 \%$ & $21.7 \%$ & $47.8 \%$ & $17.4 \%$ & 6.7 & $8 \%$ \\
\hline QA & $19.0 \%$ & $14.3 \%$ & $19.0 \%$ & $47.6 \%$ & 5.9 & $12 \%$ Q4 & $0.0 \%$ & $13.0 \%$ & $34.8 \%$ & $52.2 \%$ & 14.7 & $0 \%$ \\
\hline & & & & & 16.7 & $5 \%$ & & & & & 39.4 & $0 \%$ \\
\hline
\end{tabular}

\begin{tabular}{|c|c|c|c|c|c|c|c|c|c|c|c|c|}
\hline \multicolumn{7}{|c|}{12 Months Ended 31 Dec 2012} & \multicolumn{6}{|c|}{12 Months Ended 31 Dec 2013} \\
\hline & 01 & Q2 & $Q 3$ & at & Chisquare & P.value & 01 & Q2 & Q3 & QA & Chisquare & P.value \\
\hline Q1 & $51.7 \%$ & $20.7 \%$ & $13.8 \%$ & $0.0 \%$ & 17.2 & $0 \%$ Q1 & $37.9 \%$ & $24.1 \%$ & $13.8 \%$ & $3.4 \%$ & 8.8 & $3 \%$ \\
\hline Q & $26.1 \%$ & $34.8 \%$ & $34.8 \%$ & $13.0 \%$ & 3.1 & $38 \%$ Q2 & $17.4 \%$ & $39.1 \%$ & $26.1 \%$ & $17.4 \%$ & 2.9 & $41 \%$ \\
\hline QB & $17.4 \%$ & $30.4 \%$ & $30.4 \%$ & $30.4 \%$ & 1.3 & $72 \%$ Q3 & $34.8 \%$ & $17.4 \%$ & $13.0 \%$ & $34.8 \%$ & 3.6 & $31 \%$ \\
\hline QA & $0.0 \%$ & $13.0 \%$ & $26.1 \%$ & $69.6 \%$ & 25.3 & $0 \%[04$ & $13.0 \%$ & $17.4 \%$ & $34.8 \%$ & $47.8 \%$ & 7.5 & $6 \%$ \\
\hline & & & & & 47.0 & $0 \%$ & & & & & 22.8 & $1 \%$ \\
\hline
\end{tabular}

\begin{tabular}{|l|c|c|c|c|r|r|}
\hline \multicolumn{7}{|c|}{ 12Nonths Ended31 Dec 2011 } \\
\hline & Q1 & Q2 & QB & Q4 & Chissuare & P.value \\
\hline Q1 & $51.7 \%$ & $3.4 \%$ & $10.3 \%$ & $20.7 \%$ & 16.4 & $0 \%$ \\
\hline Q2 & $21.7 \%$ & $13.0 \%$ & $30.4 \%$ & $26.1 \%$ & 1.7 & $64 \%$ \\
\hline Q3 & $26.1 \%$ & $39.1 \%$ & $13.0 \%$ & $13.0 \%$ & 4.5 & $21 \%$ \\
\hline Q4 & $26.1 \%$ & $26.1 \%$ & $26.1 \%$ & $21.7 \%$ & 0.1 & $99 \%$ \\
\hline & & & & & 22.7 & $1 \%$ \\
\hline
\end{tabular}

Table 11. Volatility persistence of SA equity unit trusts - annual results

\begin{tabular}{|l|c|c|c|c|r|r|r|r|c|c|c|r|r|}
\hline \multicolumn{7}{|c|}{ 12 Nonths Ended 31 Dec 2004 } & \multicolumn{7}{|c|}{ 12 Months Ended 31 Dec 2005 } \\
\hline & Q1 & Q2 & Q3 & Q4 & Chisquare & P.value & Q1 & Q2 & Q3 & Q4 & Chisquare & P.value \\
\hline Q1 & $30.8 \%$ & $30.8 \%$ & $23.1 \%$ & $15.4 \%$ & 0.8 & $84 \%$ & Q1 & $46.2 \%$ & $23.1 \%$ & $23.1 \%$ & $7.7 \%$ & 3.9 & $27 \%$ \\
\hline Q2 & $38.5 \%$ & $15.4 \%$ & $38.5 \%$ & $7.7 \%$ & 3.9 & $27 \%$ & Q2 & $21.4 \%$ & $28.6 \%$ & $50.0 \%$ & $0.0 \%$ & 7.1 & $7 \%$ \\
\hline Q3 & $14.3 \%$ & $42.9 \%$ & $14.3 \%$ & $28.6 \%$ & 3.1 & $37 \%$ & Q3 & $14.3 \%$ & $42.9 \%$ & $14.3 \%$ & $28.6 \%$ & 3.1 & $37 \%$ \\
\hline Q4 & $14.3 \%$ & $14.3 \%$ & $28.6 \%$ & $42.9 \%$ & 3.1 & $37 \%$ & Q4 & $7.7 \%$ & $15.4 \%$ & $30.8 \%$ & $46.2 \%$ & 4.5 & $21 \%$ \\
\hline & & & & 0.9 & 11.1 & $27 \%$ & & & & & & 18.7 & $3 \%$ \\
\hline
\end{tabular}

\begin{tabular}{|c|c|c|c|c|c|c|c|c|c|c|c|c|}
\hline \multicolumn{7}{|c|}{12 Months Ended 31 Dec 2006} & \multicolumn{6}{|c|}{12 Months Ended 31 Dec 2007} \\
\hline & Q1 & Q2 & Q3 & Q4 & Chisquare & P.value & Q1 & Q2 & Q3 & Q4 & Chisquare & P-value \\
\hline Q1 & $38.5 \%$ & $38.5 \%$ & $15.4 \%$ & $7.7 \%$ & 3.9 & $27 \% Q_{Q}$ & $52.9 \%$ & $17.6 \%$ & $23.5 \%$ & $5.9 \%$ & 8.2 & $4 \%$ \\
\hline Q2 & $18.8 \%$ & $37.5 \%$ & $31.3 \%$ & $12.5 \%$ & 2.5 & $48 \% Q$ & $23.5 \%$ & $29.4 \%$ & $41.2 \%$ & $5.9 \%$ & 4.4 & $22 \%$ \\
\hline Q3 & $31.3 \%$ & $12.5 \%$ & $43.8 \%$ & $12.5 \%$ & 4.5 & $21 \%$ Q & $0.0 \%$ & $31.3 \%$ & $37.5 \%$ & $31.3 \%$ & 5.5 & $14 \%$ \\
\hline Q4 & $25.0 \%$ & $16.7 \%$ & $16.7 \%$ & $41.7 \%$ & 2.0 & $57 \%$ Q & $10.0 \%$ & $10.0 \%$ & $10.0 \%$ & $70.0 \%$ & 10.8 & $1 \%$ \\
\hline & & & & & 12.9 & $17 \%$ & & & & & 28.9 & $0 \%$ \\
\hline
\end{tabular}




\begin{tabular}{|c|c|c|c|c|c|c|c|c|c|c|c|c|}
\hline \multicolumn{7}{|c|}{12 Months Ended 31 Dec 2008} & \multicolumn{6}{|c|}{12 Nonths Ended 31 Dec 2009} \\
\hline & Q1 & Q2 & QB & Q4 & Chisquare & P.value & Q1 & Q2 & Q3 & Q4 & Chisquare & P.value \\
\hline Q1 & $50.0 \%$ & $12.5 \%$ & $18.8 \%$ & $18.8 \%$ & 5.5 & $14 \%$ & $38.9 \%$ & $38.9 \%$ & $5.6 \%$ & $16.7 \%$ & 6.0 & $11 \%$ \\
\hline Q2 & $11.1 \%$ & $33.3 \%$ & $27.8 \%$ & $27.8 \%$ & 2.0 & $57 \% Q_{2}$ & $25.0 \%$ & $35.0 \%$ & $25.0 \%$ & $15 . \%$ & 1.6 & $66 \%$ \\
\hline Q3 & $14.3 \%$ & $28.6 \%$ & $33.3 \%$ & $23.8 \%$ & 1.7 & $64 \%$ & $19.0 \%$ & $23.8 \%$ & $47.6 \%$ & $9.5 \%$ & 6.6 & $9 \%$ \\
\hline Q4 & $20.0 \%$ & $26.7 \%$ & $20.0 \%$ & $33.3 \%$ & 0.7 & $87 \%$ & $25.0 \%$ & $10.0 \%$ & $35.0 \%$ & $30.0 \%$ & 2.8 & $42 \%$ \\
\hline & & & & & 9.9 & $30 \%$ & & & & & 17.0 & $5 \%$ \\
\hline
\end{tabular}

\begin{tabular}{|l|c|c|c|c|c|c|c|c|c|c|r|r|}
\hline \multicolumn{1}{|c|}{ 12 Noniths Ended 31 Dec 2010 } & \multicolumn{1}{|c|}{ 12 Months Ended 31 Dec 2011 } \\
\hline & Q1 & Q2 & Q3 & Q4 & Chi-square & P.value & Q1 & Q2 & Q3 & Q4 & Chi-square & P.value \\
\hline Q1 & $45.8 \%$ & $25.0 \%$ & $16.7 \%$ & $12.5 \%$ & 6.3 & $10 \%$ Q1 & $62.5 \%$ & $29.2 \%$ & $8.3 \%$ & $0.0 \%$ & 22.3 & $0 \%$ \\
\hline Q2 & $39.1 \%$ & $34.8 \%$ & $8.7 \%$ & $17.4 \%$ & 5.7 & $13 \%$ Q2 & $20.0 \%$ & $32.0 \%$ & $28.0 \%$ & $20.0 \%$ & 1.1 & $78 \%$ \\
\hline Q3 & $12.5 \%$ & $20.8 \%$ & $45.8 \%$ & $20.8 \%$ & 6.0 & $11 \%$ Q3 & $12.0 \%$ & $36.0 \%$ & $28.0 \%$ & $24.0 \%$ & 3.0 & $39 \%$ \\
\hline Q4 & $0.0 \%$ & $18.8 \%$ & $37.5 \%$ & $43.8 \%$ & 7.5 & $6 \%$ Q4 & $4.2 \%$ & $0.0 \%$ & $37.5 \%$ & $58.3 \%$ & 22.3 & $0 \%$ \\
\hline & & & & & 25.5 & $0 \%$ & & & & & 48.7 & $0 \%$ \\
\hline
\end{tabular}

\begin{tabular}{|c|c|c|c|c|c|c|c|c|c|c|c|c|}
\hline \multicolumn{7}{|c|}{12 Nonths Ended 31 Dec 2012} & \multicolumn{6}{|c|}{12 Months Ended 31 Dec 2013} \\
\hline & Q1 & Q2 & Q3 & QA & Chi-square & P.value & Q1 & Q2 & Q3 & Q4 & Chi-square & P.value \\
\hline Q1 & $41.7 \%$ & $25 . \%$ & $20.8 \%$ & $12.5 \%$ & 4.3 & \begin{tabular}{ll|l|}
$23 \%$ & 01 \\
\end{tabular} & $33.3 \%$ & $12.5 \%$ & $20.8 \%$ & $20.8 \%$ & 2.5 & $48 \%$ \\
\hline$Q 2$ & $28.0 \%$ & $36.0 \%$ & $32.0 \%$ & $4.0 \%$ & 6.2 & $10 \% \sqrt{Q 2}$ & $36.0 \%$ & $12.0 \%$ & $24.0 \%$ & $28.0 \%$ & 3.0 & $39 \%$ \\
\hline$Q 3$ & $16.0 \%$ & $28.0 \%$ & $16.0 \%$ & $40.0 \%$ & 4.0 & $27 \%[Q 3$ & $16.0 \%$ & $32.0 \%$ & $24.0 \%$ & $24.0 \%$ & 1.3 & $72 \%$ \\
\hline$Q 4$ & $12.5 \%$ & $12.5 \%$ & $33.3 \%$ & $50.0 \%$ & 9.7 & $2 \%(04$ & $25.0 \%$ & $41.7 \%$ & $25.0 \%$ & $12.5 \%$ & 4.2 & $24 \%$ \\
\hline & & & & & 24.2 & $0 \%$ & & & & & 11.0 & $28 \%$ \\
\hline
\end{tabular}

\begin{tabular}{|l|c|c|c|c|r|r|}
\hline \multicolumn{7}{|c|}{12 Nonths Ended 31 Dec 2014 } \\
\hline & Q1 & Q2 & Q3 & QA & Chi-square & P.value \\
\hline Q1 & $66.7 \%$ & $8.3 \%$ & $16.7 \%$ & $20.8 \%$ & 20.2 & $0 \%$ \\
\hline Q2 & $16.0 \%$ & $16.0 \%$ & $20.0 \%$ & $32.0 \%$ & 2.4 & $50 \%$ \\
\hline Q3 & $16.0 \%$ & $24.0 \%$ & $24.0 \%$ & $20.0 \%$ & 1.1 & $78 \%$ \\
\hline Q4 & $29.2 \%$ & $25.0 \%$ & $16.7 \%$ & $16.7 \%$ & 1.5 & $68 \%$ \\
\hline & & & & & 25.1 & $0 \%$ \\
\hline
\end{tabular}

\section{Copyrights}

Copyright for this article is retained by the author(s), with first publication rights granted to the journal.

This is an open-access article distributed under the terms and conditions of the Creative Commons Attribution license which permits unrestricted use, distribution, and reproduction in any medium, provided the original work is properly cited. 